\title{
Encounters with haunted industrial workplaces and emotions of loss: class-related senses of place within the memories of metalworkers
}

cultural geographies 20(4) 467-483

(C) The Author(s) 2012 Reprints and permissions: sagepub.co.uk/journalsPermissions.nav DOI: 10.1 I77/I4744740I 2469003 cgj.sagepub.com @SAGE

\section{Lars Meier}

Technical University Berlin, Germany

\begin{abstract}
This article is about the relevance of social class within emotional geography. Based on life history interviews with former metalworkers in Bavaria, it analyses their identity-related sense of place and the feelings of loss they experience when encountering their former places of work. By concentrating on the perspective of those who have worked on industrial sites, and their encounters with those sites, now transformed, this article focuses on a specific identity-related emotion experienced by working-class people, which is often underestimated. Recollections of common experiences linked to the workplace may seem haunting in the form of memories of body routines within a place ballet, or of former buildings and walls. Workers describe how, when they visit their former workplace, they have to confront this haunting from the past; and it is through these haunting experiences that their class identity takes on a new but often painful existence.
\end{abstract}

\section{Keywords}

emotions, haunting, memory, sense of place, working class

\section{Introduction}

On the 22nd September 2002, in the Maxhütte in Sulzbach-Rosenberg, approximately 800 workers poured hot liquid steel into the blast furnace and took the cooled product to the rolling mill for the last time. Following the shutdown of the Maxhütte, ${ }^{1}$ the last steel works with a blast furnace in Bavaria Germany, most of the rolling mill was scrapped, and the casting machine sold to China.

Corresponding author:

Lars Meier, Department of Sociology, Technical University Berlin, Fraunhoferstrasse 33-36, 10587 Berlin, Germany.

Email: lars.meier@tu-berlin.de 
Today there is little left of the Maxhütte. Just a large - and contaminated - slag heap, gutted buildings, and the remains of the blast furnace on a 60 hectare industrial area. But even though nearly everything to do with the former steel work is gone, former workers sometimes climb a nearby hill called the Schlossberg for another look at what was once their workplace.

Sixty-six-year-old Karl ${ }^{2}$ who worked as an engine driver for 26 years at the Maxhütte, describes a regular occurrence at the Schlossberg:

People arrive at six o'clock in the morning - as if the blast-furnace was still there. Many come every day to the Maxhütte, just to look. And these are often people who are already getting their pension. What a picture of misery. Yes it is a picture of misery. The closure of the steelworks was the kind of life event that you never forget. It's different if a company doesn't have any particular importance for you. If you can say 'well, I was just a number in the company'. Then that's okay for you. But this was my company, and that's what everybody who worked there said about it. 'It was my company.' (Karl, 66 years, former engine driver)

Industrial ruins are metaphors of transition and change, ${ }^{3}$ as well as material structures that were, in former times, suitable to a specific regime of accumulation ${ }^{4}$ as 'an inevitable result of capitalist development'. ${ }^{5}$ Sites and ruins transformed by time hold information about change in politicaleconomic and social structures. The focus of this paper is on the memories of those who have experienced such transformations within their working life. As Karl remembers in the sequence above, transformed workplaces continue to attract former workers and awaken strong emotions. The ex-workers, now pensioned, are drawn to their former workplaces, even if those places are

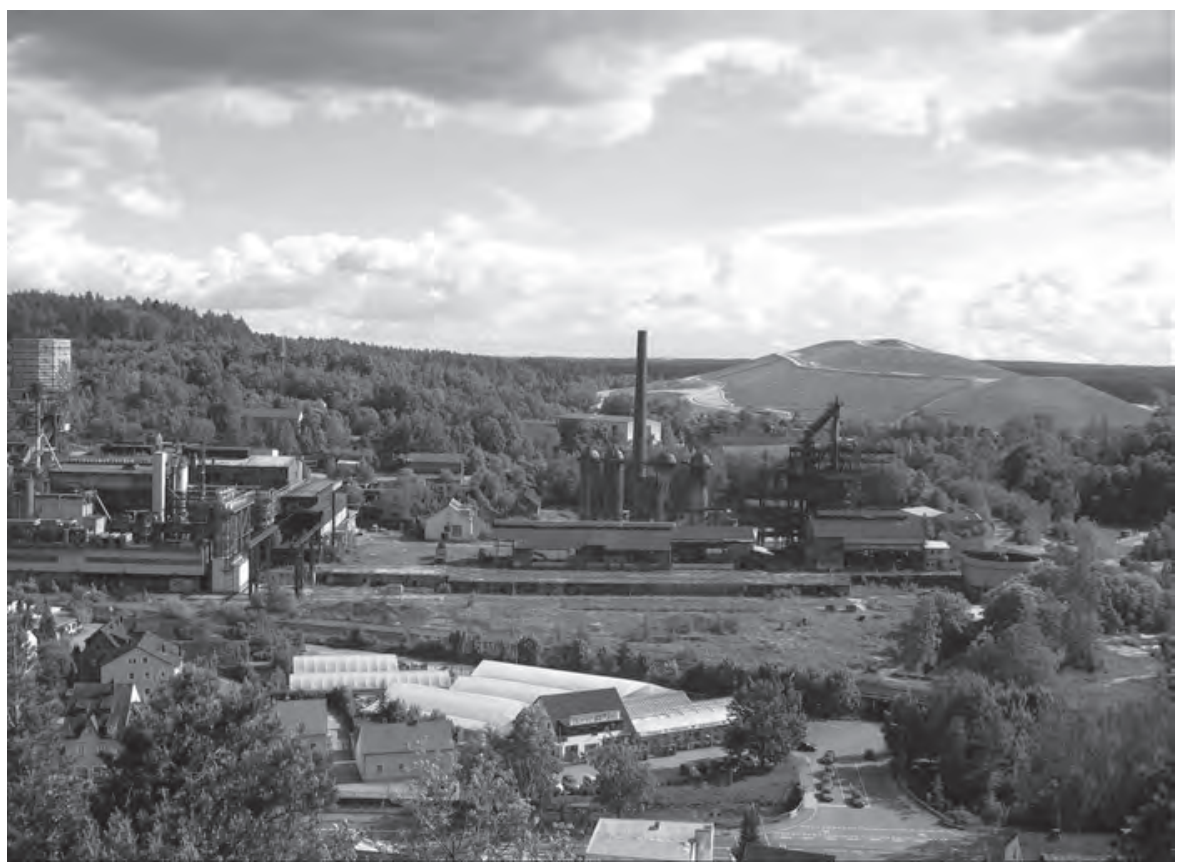

Figure I. The Maxhütte seen from the Schlossberg, taken by Lars Meier in June 2012. 
now in a different shape, and have lost their former purpose. In the former workers' memories, that which is absent today is reincarnated in a haunting sense. What form this takes, however, depends on who is remembering.

As with studies on the politics of memory, which focus on official memory sites, this article examines the subject from a new angle. Those studies contain powerful official representations of landscapes as texts, ${ }^{6}$ containing interviews, for example, with owners of memory sites, ${ }^{7}$ the way in which these sites are represented in museums, and heritage structures under scrutiny. ${ }^{8}$ Because the Maxhütte is also an official memory site, it could be considered as a subject for this kind of research. There is an ongoing public debate about which industrial monuments and icons of a former industrial age should be saved from these ruins, for tourism purposes. In the nearby town of SulzbachRosenberg there is a museum that tells the history of the Maxhütte. The slag heap has been refurbished for possible tourism use, and the area is sometimes used for a 24-hour long mountain bike race - a world cup event.

But this is not what attracts former workers. They visit the Maxhütte because of their personal memories of the time they worked there. For them, the Maxhütte is a personal memory site. That which is missing in their lives today looms hauntingly in their memories of former times. These memories, which may well be emotional experiences, are triggered by an encounter with a former place of work, and by narrating lengthy descriptions of these former times in the context of a life history interview situation. An encounter with the Maxhütte today gives rise to vivid memories and strong emotions.

In this paper, people who worked at a particular place for a very long time, describe their recollections of their past work locations. Their memories of the place as it was and the realization of it as it is now, can be a highly emotional experience. ${ }^{9}$ They frequently have souvenirs that they display in their living rooms, such as a photograph of the factory. These bear witness to a deep emotional connection with their former place of work.

This paper considers class with reference to the work of Pierre Bourdieu within the context of practices and as an everyday experience that is embodied in peoples' history; ${ }^{10}$ and on the basis of interviews with former metalworkers in North-Bavaria, about the transformation or ruination of workplaces, it shows the relevance of class identity to be palpable. Class is not always expressed as a collective awareness of the shared social position and resulting collective interests. The 'class in itself' does not necessarily become self-aware as a 'class for itself'. ${ }^{11}$ By analysing the workers' place-related emotions, the distinction between a set of objective conditions that define class, the experience of being employed as a worker, and the subjective consciousness of one's own class position, is investigated. This article demonstrates the political aspect of supposedly very personal cultural characteristics within emotions and experiences.

\section{Absence and haunting of former times in biographic narrations}

Absence is a relative concept with a temporal dimension. What is absent today is absent from an identity-related perspective, which is fed by the specific experiences of the workers interviewed. This historical dimension is expressed in the memories within the life history interviews. ${ }^{12}$ This article is mainly based on such interviews, usually lasting between three and seven hours, and focus group interviews with groups of manual workers, ${ }^{13}$ in which a common relationship of social identity becomes especially palpable. This article refers to selected life history narrations of male and female former manual workers, over 60 years old, who have worked for some decades in Nuremberg (Bavaria). The interviewees were contacted with the help of the industrial workers union, traditional workers' sports clubs or by using addresses gained during previous expert 
interviews. After an initial phase of interviews others were contacted using the snowball system. Beginning with a general request to tell their life stories from the very beginning, the interviewees started doing exactly that. This relative openness allowed the narrators to create a meaningful story from their own lives. After this initial phase, the researcher used open questions to refer to the former narrative, and develop specific questions.

Narrations and lived experiences are an integrated issue. ${ }^{14}$ Within narrated biographic memories, identity is reconstructed by creating meaning from memories, and making one's own life into a story. ${ }^{15}$ However, these biographic narratives do not give objective or 'true' data of personal history and are not simply about lived experiences. They are also about today's constructed views and considerations of such experiences. Using such life histories, it can be seen how people make sense of their past and how they relate their individual lives within a transforming broader social context, and also a region or place. ${ }^{16}$ It is within the context of these life history interviews that a place is considered, not only in its actual representation but also as a former experience. In the workers' memories, absence is created by the relationship between what is encountered today and what is remembered from former experiences at the place of work, before the transformation occurred. The workers' sense of place and the emotions connected to their former workplace are especially strong during narrations of an imagined encounter, suggested by the interviewer, with the former workplace as it is today.

The formerly present structures, which are now absent, come alive in these memories - as hauntings, which are, in effect, present absences. The metaphor of spectral haunting has featured prominently since the end of the 1990s, ${ }^{17}$ with references to the work of Derrida. ${ }^{18}$ Against the background that the present exists only with respect to the past, he has developed the metaphor of haunting as something that folds time and unsettles the linear sense of time as it is represented. A haunting evokes a sense of injustice and triggers emotion. A haunting brings the past into the present, because what was there is remembered and given a relationship to the present by the ex-workers. As Gordon puts it, 'haunting is a very particular way of knowing what has happened or is happening. Being haunted draws us effectively, sometimes against our will and always a bit magically, into the structure of feeling of a reality we come to experience, not as cold knowledge, but as transformative recognition' ${ }^{19}$

Broader transformations and their impact on the individual life can be seen from this metaphor. Because haunting is 'a process that links an institution and an individual, a social structure and a subject, a history and a biography'. ${ }^{20}$ By referring to haunting, that which the workers have lost in the past becomes palpable here. Using this metaphor, the past becomes what is experienced and seen by the workers today. The haunting appears in conjunction with the workers visiting their former workplaces and it involuntarily creeps into their biographic interviews. It wells up inside their narratives and during encounters with the site - without them wanting this to happen in an explicit way. The haunting also has a repetitive character as it comes into being involuntarily, again and again.

Since this article is on haunting as perceived by those with former experiences of these places, it differs from the perspective of considering a ghost as a representation - or the traces of a representation of those who have gone long before, and who are now seen by others such as visitors to the site, or ghost hunters. In this article, the metaphor of haunting is considered from an identity specific perspective, with regard to the workers memories and experiences at their former places of work. The notion of haunting takes the workers back to times past. Today, from the top of the Schlossberg they see not only the remains of their former workplace but also structures and events from the past. What, for others, is hidden under the layers of the current site, is visible for the former workers. A place contains traces of former times and its previous life, structures, atmospheres, 
people and experiences. But these traces cannot be seen by everyone, only by those with experiences of the place. When encountering their workplaces today, the workers are haunted by former walls, machines or movements, which are seen and experienced exclusively by them. Those reliving their own experiences at their former place of work are haunted in such a way, proving that everyday geographies and identities are not without a past.

\section{Class matters in an emotional geography, and in the context of a sense of place}

Memories are not only an individual issue; the former manual workers come together at the Schlossberg to relate their memories and experience a shared sense of place as a class-related issue. This article demonstrates that those who worked at these now transformed places for a long period of time have a particular sense of place, related to class. Class is considered as a dynamic process here. ${ }^{21}$ This is because differences between classes are produced and reproduced through the daily practices and experiences of the individuals involved. It is this background of considering class in the context of daily practices and experiences that allows class and place to come together in this article. This is not only because the workplace was experienced by the workers on a daily basis, but also because the workers make their daily practices fit into the specific rules and structures of the workplace and its community.

The concept of a sense of place integrates an objective place and a subjective sense. ${ }^{22}$ Using this concept, objective transformations of places and landscapes and individual responses to these transformed landscapes are seen in relation to each other. It is about whatever makes a place special for a person. Place specific emotions are not only the result of objective qualities but also developed by the individual's subjective experiences there. From a phenomenological standpoint, immediate embodied experiences are integrated into the cultural rules and meanings that colour the way people behave, and how they perceive their surroundings. ${ }^{23}$ Landscape from this perspective is a lifeworld, a milieu of engagement and of involvement. It is 'a world to live in and not a scene to view, 24

By putting its focus on the narrated experiences and emotions of former workers, this article is not about experience landscapes and absence with a phenomenological background, from a personal and emotional viewpoint by a subjective self-reflexive researcher. ${ }^{25}$ Against such a background, one strand of research gives its attention to analysing the attraction of degradation and decay of cultural artefacts and ruins. ${ }^{26}$

The specific attraction of transformed or ruined places, for those who worked there before the transformation occurred, is considered in this paper to be class related. Memories and emotions are considered specific, as they are charged with being related to the social identity of class. From such a perspective, this paper aims to fill the gap of a social identity-related emotional geography. Emotional geography ${ }^{27}$ is worked out mainly on the basis of personal identities and experiences. And when emotional geography is considered as a social identity-related issue, it is usually worked out using the example of gender identity. ${ }^{28}$

Memory is not only central to self, but also a social activity. This is because it can be a collective matter, an expression and binding force of a social group identity. ${ }^{29}$ Biographic memories are therefore involved in the relationship between individual and social, as well as between past and present. Central elements within the biographic memories of the workers are related to family, relatives, work and home. These memories are spatially bound ${ }^{30}$ by places and landscapes, which are, in effect, 'storehouses' of social and personal memories, ${ }^{31}$ and are bound up with processes of emotional attachment. ${ }^{32}$ For the workers, the strong emotional attachment to the workplace remains, 
even if it is transformed and they are of pensionable age. Bernd, a former Grundig worker, has such strong emotional attachments that he experiences them in his dreams:

Lars: 'How do you feel when you drive past the Grundig site. What do you think?'

Bernd: 'There is still a feeling of coming home ... It's just that I liked it to be there. The worst thing is that I still dream of that time . . . Of the work, really, I dream of the division. In my dreams I sometimes go in and can’t ever find my way out. Or sometimes I drive in, and put my car in my parking spot, and when I want to go home I can’t find my car. (both laughing) Totally crazy.'

Lars: 'That means you can't get away, then?'

Bernd: 'Yes' (12)

Lars: 'And what do you think it is that won't let you go?'

Bernd: 'I don't know. I don't know. The longing for home or (I: Yes) I don't know. (11) A few times I dreamt that I was going there - towards Grundig, Langwasser. But I can't find the way. It's very strange.'

This emotional attachment to a place is made clear by an accompanying narration that articulates identity. The interviewees do not set their life narratives and experiences in a direct relationship to a class position. Their narratives are the constructions of individuality. It may be argued that this is because any inference of lifestyle, behaviour or interests resulting from class membership, casts doubt on individuality. Class is in constant contradiction to a powerful social discourse that propagates individual freedom and self-fulfilment. ${ }^{33}$

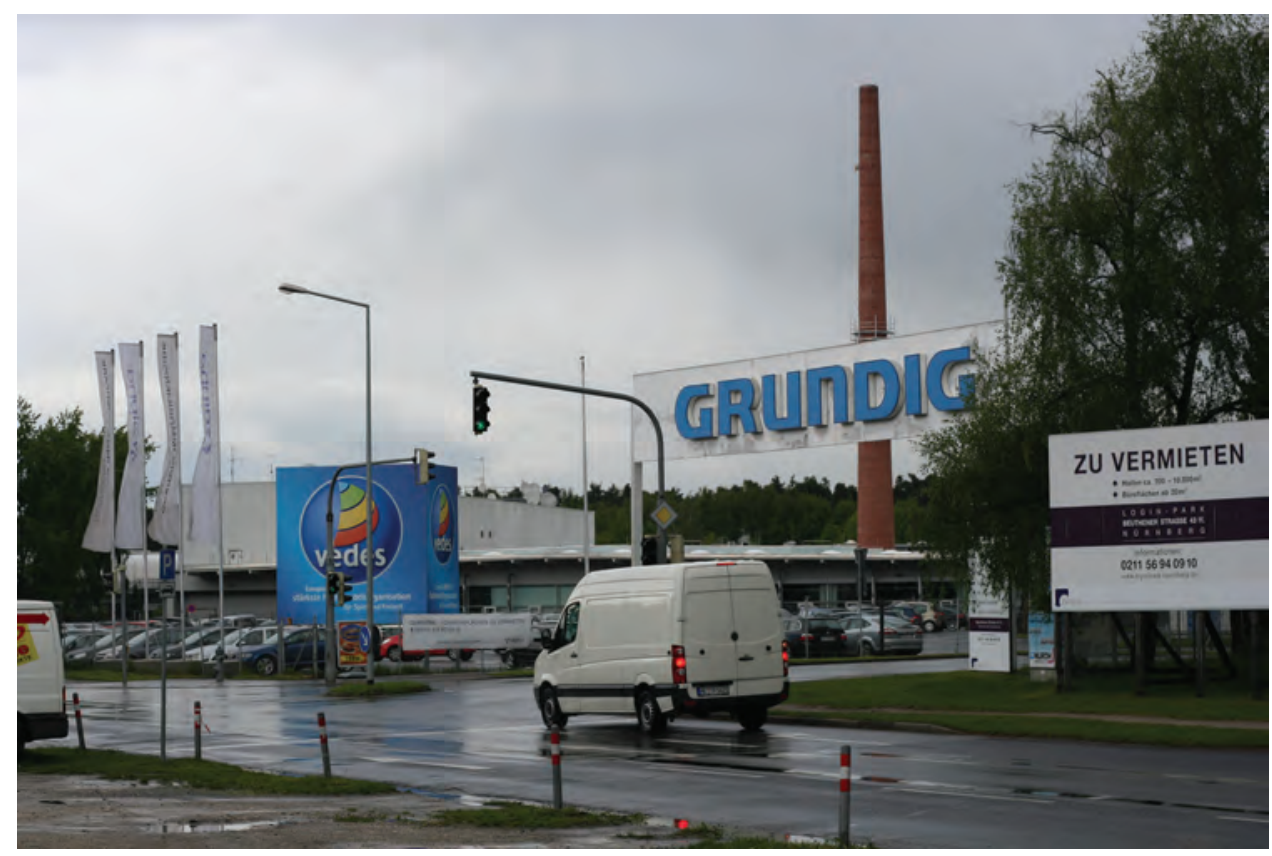

Figure 2. Former main entrance of the Grundig plant, taken by Lars Meier in June 2012. 
The way in which we see and experience places is identity related. People define themselves through places. The memories of ex-workers are connected to specific sites and communities - when their fellow workers occupied the landscape in question, for example. A sense of place, or a place identity is explained by psychologists as very personal - 'a component of personal identity, a process by which, through interaction with places, people describe themselves in terms of belonging to a specific place' ${ }^{34}$ But a sense of place is not entirely the result of individual experiences, emotions and meanings. ${ }^{35}$ The workers' memories are not only an issue of a personal identity but also of their social class identity. Emotional relationships and feelings of affiliation to the workplace develop over a long period of time, ${ }^{36}$ through everyday experiences at its structure, rhythm and atmosphere and in a place-related worker community. A sense of place is an emotional link to a place, which has developed out of former experiences. Fleeting placements of moving material and people leave their mark in both the geography and also in the memory. By considering class identity by practices and experiences, the sense of place is seen here as one that is class related. By recalling former encounters with other workers and consequently remembering the integration of self and the body into everyday work routines and rhythms at the workplace their class identity is indirectly reflected in their memories. It comes as no surprise that the place of work has a central role in the interviewees' biographic narratives, and is indirectly related to their identities as workers.

These encounters with former workplaces give rise to strong emotions in those who worked there for an extended period of time. Their memories of the daily routines that took place there, as well as their past integration into a community, change their perception of the place. It becomes, for the interviewees, a home, and an 'irreplaceable centre of significance'. ${ }^{37}$ Inclusion into a workplace and its community brings about a shift in the individual's emotional relationship to it. The development of a class-related sense of place can be seen in the narrated memories of the workers. Gerda, a former warehouse clerk born in 1952, who worked for 36 years in the AEG plant in Nuremberg - closed in 2006 - remembers a change in her personal perception, which is associated with the development of a sense of belonging to the workplace.

When I was a child my parents and I frequently passed the AEG plant, and I would look at it and always think, 'What an ugly building. I never want to work there' ... But time went by, and I did work at the plant and it didn't seem to be ugly anymore. (Laughs) And eventually, it became like a second family to me. For 15 years, I looked forward to going to work. I would rather have let someone cut off my head than believe that the AEG plant would close. I never thought it would happen. It was a shock for me. (Gerda)

With the integration of the individual as a working person into a workplace, the work process and the community, their emotional relationship to a place alters. For Gerda, the AEG plant was transformed from an ugly building to become 'like a second family'. Her inclusion as a worker, into the entire and rounded work process, made her feel like an integral part of the place, which then - for her, was not ugly anymore. This kind of close contact inevitably brings about a development of a sense of place, which in turn means that the worker's identity alters and becomes closely connected to the workplace, its community and the work processes. With the closure of the factory, this inclusion as an integral part of the workplace and its community is lost. But this does not leave feelings of emotional indifference towards the building once regarded as ugly. In the same way that Gerda's sense of place was once before dramatically changed by her integration into the plant that 'became like a second family', the closure for her was a huge shock. And the emotions she experienced were similar to Karl's, described in the narration above as 'this was my company, and that's what everybody who worked there said about it'. Karl further 


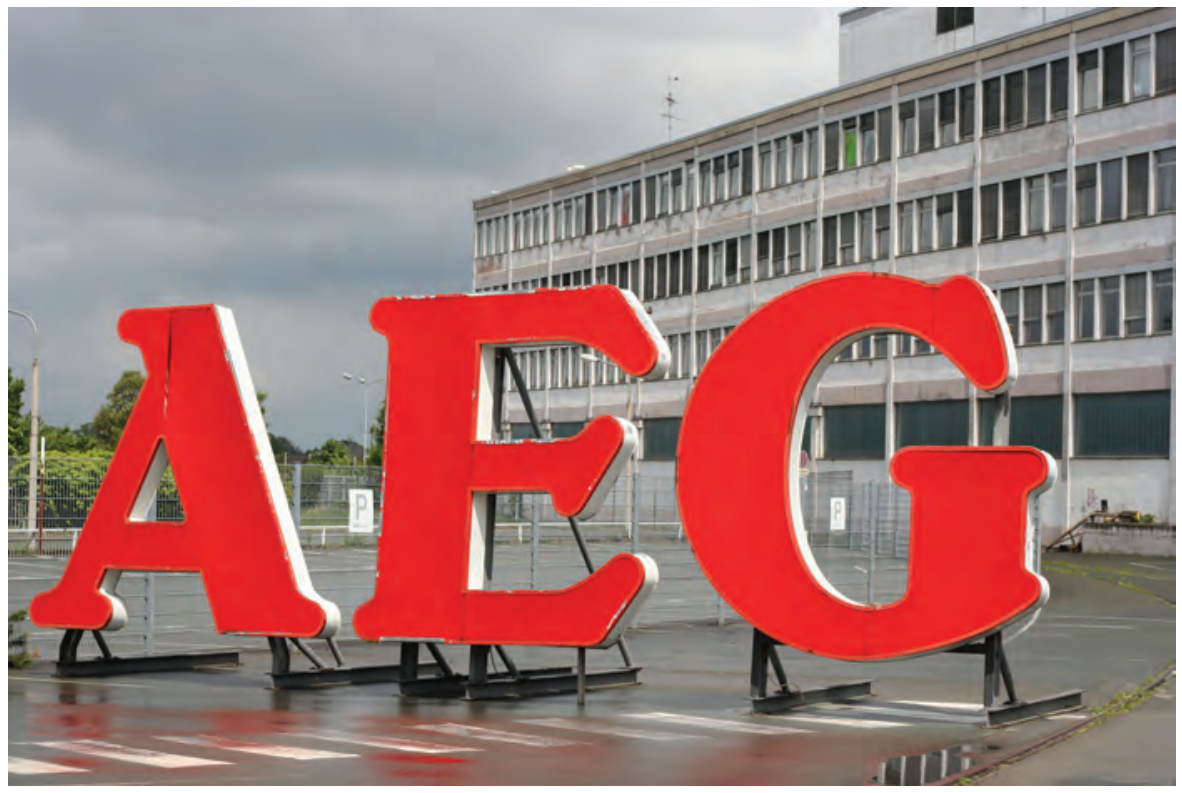

Figure 3. The AEG sign, which was highly visible on the top of the AEG main office building, now, after the closure, stands besides the building. Taken by Lars Meier in June 2012.

describes his relationship to his former workplace when he explains that he never felt like 'just a number'.

These former workers consider their position as being much more than 'just a number', in an industrial plant that was - and is - seen by them as 'a second family' or as 'my company'. Within these interviews it becomes obvious that the workers did not see their positions in the workplace as a purely functional arrangement of capitalist labour. That labour is a commodity, and that the aim of the management and the owner of the plant was to accumulate capital out of gaining the surplus from their labour, doesn't feature in their view of their roles as workers within the former plant.

With the closure of the plant, the feelings of inclusion into the place and also the place-related identity are dramatically affected. As the plant - the 'second family' or 'my company' - is closed, place bound integration into a working community - seen as a family structure - is dissolved. When encountering the closed plant today, the former workers' belief that they were not just numbers and that the plant and its community was like their 'second family', (Gerda) is shattered. In encountering what is left of the plant today, it becomes obvious to them that the work and production process they were included in, through their role and function as a worker, ultimately meant that each was in fact a number and part of a working body. The belief that each was a member of a 'second family' is destroyed. The encounter with the transformed or ruined workplace today is a shock for them, because it is now clear that they were in the production process just workers who, unlike the owners of the plant, had no say in decisions on its development.

\section{A nostalgic haunting of former good times and horrific emotions}

Places and landscapes are the products of human activity and labour, and accordingly, are always in the process of becoming. ${ }^{38}$ Features such as materiality, atmosphere, rhythm, and people, may be 
altered and rearranged, but still their former structures have some resilience. It is this durability of meaning and of materialities that show the transformation of what was there before and is now absent. In heritage buildings and monuments, these traces are rearranged as visible and powerful memory structures for the public. ${ }^{39}$ However, within these solid structures there are also traces that are visible only to those who have specific memories of their own experiences at the corresponding place, and invisible to all others. These traces of former times can be fairly easily discerned, and are visible, for example, in a steel framework, as explained by Karl in the following interview excerpt:

I visited the Maxhütte with some former colleagues; or rather I visited what is left of the Maxhütte today. It brought tears to my eyes, because now you can only see the steel framework. I said to myself: 'This was my workplace, I worked there.' The blast furnace was there, the roller mill was there, and and the steel mill was there. And now there are only naked steel frameworks. Nothing works anymore. For me this is ... (he takes a deep breath) like looking at a dead person. I look from above the plant, from the Schlossberg, as it's called, directly down onto the Maxhütte. And I say, 'no, it's not possible. Once eight or nine thousand people worked there - and now it's all over' . . . Today Sulzbach-Rosenberg is like a city of the dead. Before, there was life, there was action and and ... now there is nothing... And if you saw the people - 60, 65 years old - crying like small children as the plant went down the drain. 'My company is dying', they said. That was their Maxhütte. (Karl, 66 years, former engine driver)

When he looks at what is left of the Maxhütte, Karl perceives more than simply the visible traces, such as the 'naked steel frameworks'. His experiences as a worker at the Maxhütte have a keen influence on what he sees today. When he sees it from the Schlossberg his memories come alive. He looks at the material traces remaining, and he remembers that 'there was life'. His awakening memories, while viewing the plant from the Schlossberg, make his encounter with the Maxhütte an emotional experience. In Karl's narrative, he describes how his former workplace now appears as a 'dead person' with 'naked steel frameworks' where 'nothing works anymore'. The scene becomes filled with absences for Karl, as a result of seeing it in the context of remembered experiences from former times. If he encounters these 'naked steel frameworks' today, Karl can see what is today not there for the others - but is still, because of his memories, there for him.

Karl remembers and sees, in his mind's eye, that 'the blast furnace was there, the roller mill was there, and and the steel mill was there', and he cannot separate this knowledge from the scene in front of him. When he encounters the Maxhütte today, Karl's perception of the area and his experiences there are, in effect, led by what is now absent for him but which still haunts him - making it for him, at any rate, still there. The former Maxhütte, its blast furnace, roller mill and steel mill are, to Karl, spectres from the past that continue to haunt him. Maddern and Adey write that 'the figure of the ghost is often used as a means of apprehending that which we cannot explain, do not expect, understand, or struggle to represent'. ${ }^{40}$ Karl also says that he 'cannot believe this' and has no reasonable explanation of what has occurred. He says,

It makes my heart ache. It's so hard to believe. I was there for 26 years, it was my company, and seeing it ruined like this, for no reason, is very hard for me to take in. Now it is like a dying giant. (Karl, 66 years, former engine driver)

The strong emotions evoked by encounters with former workplaces, now shut down or completely transformed, can be compared to a grieving process. Karl is expressing a feeling of shock combined with a denial of loss in his explanation that his 'heart aches' if he drives by the Maxhütte today. Other interviewees express great sorrow when they are confronted with their former workplaces - plants, such as Grundig, AEG or MAN, for instance. Lydia, a former worker in the closed Grundig plant in Nuremberg, describes how she feels when she drives past the former plant: 
Sometimes I start crying. I had some very good times there. Bad times too - but it was like my apartment - like my home ... It's where I grew up, right? That's where I grew up. I was 18 years old when I started work there [1984]. It's not easy. I'm really sorry that a well known company like that closed down ... I had a few colleagues, who actually became ill after the company closed down. Physically ill. Thirty years of work and then finished. Just like that. It's not easy. (Lydia)

When Gerda drives past the former AEG building today, she feels very emotional:

I look the other way (laughs) . . . Yes, with a sad glance, actually. Because a) it's not very often that I drive past it, and b) because it still hurts when I think about it or when I see what happened to AEG. What they did to the company. They totally cut it into pieces, right? It's no longer the AEG company I know. So of course it hurts when I look at it. (Gerda)

For the members of the focus group, encountering the industrial area of the MAN is an emotionally demanding task. And driving past it automatically gives rise to strong feelings.

Lars: $\quad$ 'How do you feel when you drive by these buildings, which are being used so differently now?'

Manfred: 'Well, it hurts. It hurts, when you drive by them, when you've worked there a whole lifetime.'

Christian: 'Yes, it definitely brings back memories.'

Manfred: 'Of course.'...

Ex-workers encountering their former working place today find that it involves the energy sapping process of mourning a loss. Driving to his former workplace, Karl confronts his loss and considers what he remembers about it - and the haunts that are for him, still there. He says,

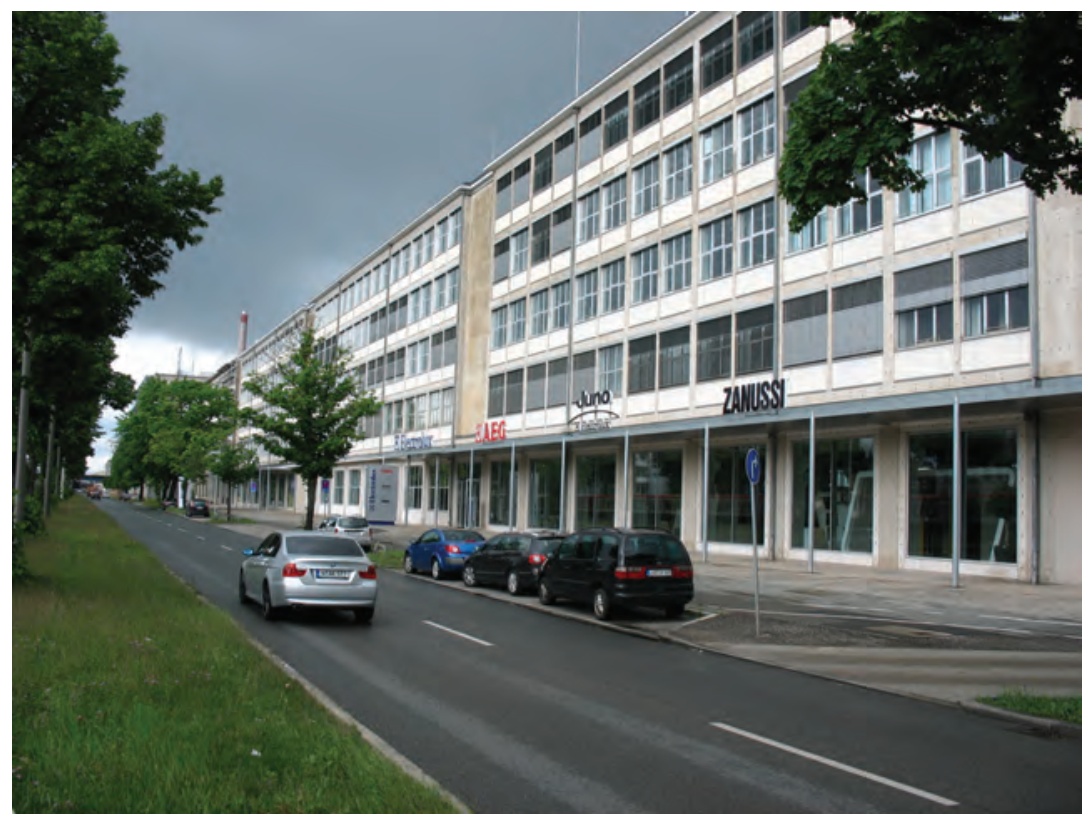

Figure 4. Former AEG building seen from the Fürther Strasse. This area is now used for various purposes. Taken by Lars Meier in June 2012. 
Sometimes I find myself stopping by Sulzbach-Rosenberg. Then I go up to the Schlossberg and look down and I think: 'Hey, Karl, you worked there, in the shunting operation, then you drove there in a locomotive. You picked up the train there, and you fuelled the blast-furnace with coke, there.' And now there is nothing left. (Karl, 66 years, former engine driver)

In confronting the Maxhütte, Karl imagines the routes he used to take, every day across the site. Karl remembers these movements as inextricably connected to the functioning of the entire industrial work and production process of the Maxhütte. But when he visits the Maxhütte, his memories aren't only of his own everyday working routines and movements. Because he sees his role as an integral part of the industrial area - which in turn was such a large part of the entire production process of, as Karl puts it 'my company', he references that role as being a vital part of the whole work and production process in the Maxhütte.

Karl's routine body movements as an individual worker were part of an environment where such individual time-spaces and body routines commingled in a larger dynamic of interactions between several such individual time-space and body routines. David Seamon ${ }^{41}$ conceptualized this as place ballet ${ }^{42}$ a process where communal exchanges and actions occur. Karl's memories are of his 'body ballet' performance - his body moves and its time-space activities, fitting perfectly within the whole organization of the work processes, is an integral part of a place ballet at the Maxhütte. Today, an encounter with the Maxhütte means that this 'ballet' comes back to haunt Karl without his volition. While others see only today's remaining and transformed material structures, he sees the 'ballet' movements within the area. This is due to his own experiences as a worker there.

Class is a social identity that is based on common experiences, practices and memories. In focus group interviews with a number of workers, a class-related sense of place became especially obvious. This is because within a group of workers with similar experiences a common sense of place is developed within the narratives, as the memories of each worker provoke additional memories from the others. Within the interviews, a common narrative of the group develops and memories of common experiences and practices in the former workplace (which, with reference to Bourdieu, are considered here as class related) are generated. Five ex-MAN workers, all over 60, consider the transformation of the factory site as a place where a sense of absence is evoked. In swapping memories of the past, they express a shared relationship to the plant area and its former condition. By remembering its exact former appearance and what is now lost, they express their common emotional relationship to the plant:

Paul: $\quad$ 'Of course the site has changed substantially. After all much has been sold.'

Oliver: 'To clarify what has changed - today, if you go out onto Vogelweiherstraße and straight on and then turn right, there is a short length of wall close to Gugelstraße that has been knocked down. But back then, the wall was intact, all the way up to . . . Frankenstraße, and to Katzwangerstraße.'

Paul: 'Up to the administrative building, right?'

Oliver: 'And where there is no wall anymore, all that used to be part of the site. It all belonged to MAN - and now it's all gone . . . The place where the administration for the entire MAN company in Nuremberg used to be - that's all been sold, everything is gone. Everything's gone. There, where the Frankencampus is, all that used to be the MAN administrative building.'

Manfred: ' 'For the entire MAN company in Nuremberg.'

Christian: 'And the old administrative building - the front building, doesn't exist anymore. There's only the Klett left. The entire brick building is gone.' 


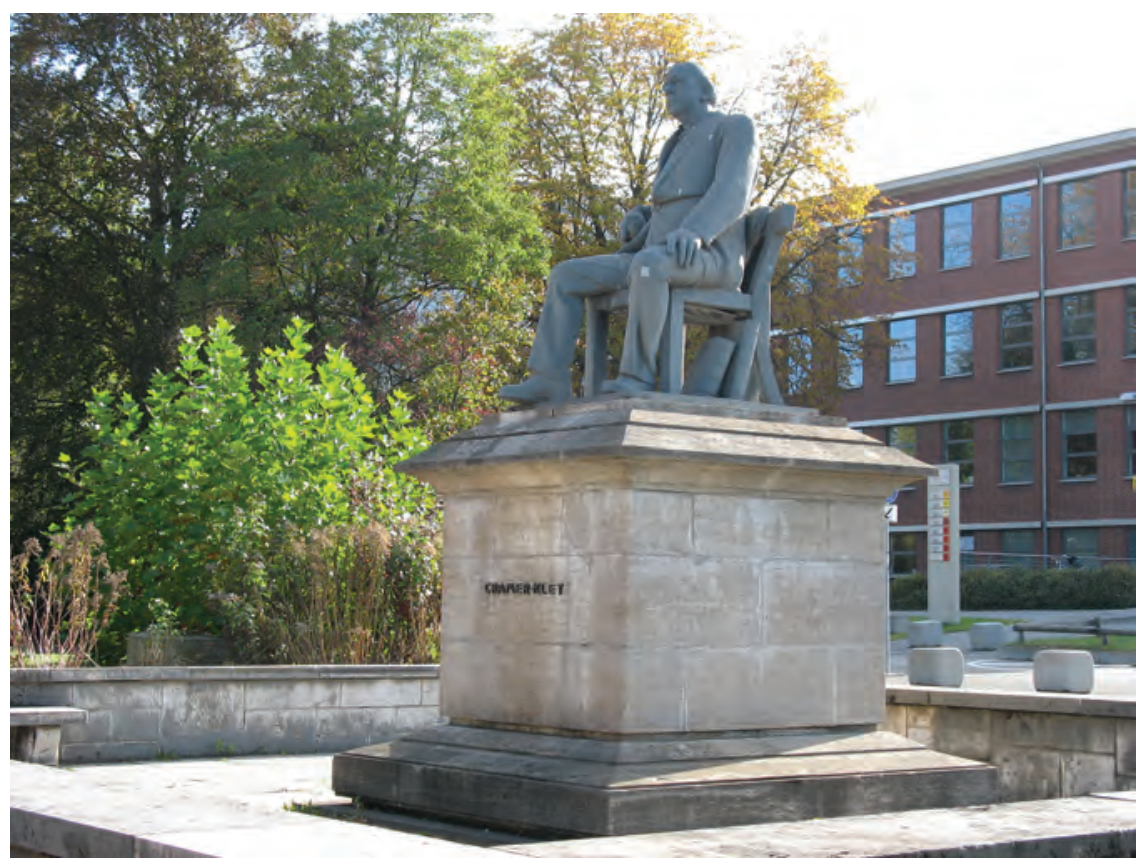

Figure 5. The statue of Mr Cramer Klett, now in front of the newly erected Frankencampus. Taken by Lars Meier in October 2009.

By sharing their common memories within their conversation, together they awake the haunts of walls and buildings. The now absent former structure is born again through the common memory of the former workers. And these memories also trigger recollections of social relationships within the workplace, former working routines and everyday body movements, all of which are expressed in the interviews.

By also conceptualizing class as a specific kind of experience that is expressed in personal histories, it is clear that the former workers are aware of their class identity, when confronted with their former workplace, and when they consider what is now absent. Karl's strong emotional relationship to the Maxhütte and his feeling that this was his company, articulates Karl's sense that he was not just a number or a working body. That this view of his role in the company was an illusion, or a false consciousness of his class situation, ${ }^{43}$ became obvious for the former worker, during the encounter with the destroyed or heavily transformed factory, which happened without his approval.

For the former workers, their everyday experiences at the workplace were not those of a number, or simply of a working body. They look back on their integration into a community where, as well as being a worker, each was an individual and not just an anonymous number. During encounters with the workplace today, the haunting of such yesterday's everyday experiences appears involuntary and painful. They are nostalgic hauntings of a former better and harmonious time, which effectively hides the logic of a capitalist production mode. But this is in sharp contrast to the manager's decision to close the plant and dismiss the workers, at which point it became obvious to them that they were also simply numbers in a capitalist economic logic.

Some argue that work has lost its relevance to identity in late capitalism. Ulrich Beck has used this argument to see class as a 'zombie category', which though still alive in theory, ${ }^{44}$ is dead 
within the reality of individuals in flexible and insecure labour markets. But Karl remembers common experiences of work - demonstrated also by his inclusion into the place ballet and still vivid in his memory - which demonstrate the opposite; namely, that work is essential for the development of class identity via shared labour experiences. Against the thesis that work has lost relevance for identity, which is criticized as data free, the continuing relevance of class to income or health, and to everyday experiences as well as the concept of the self, is demonstrated in diverse studies, as in this article. MacKenzie et al. ${ }^{45}$ have shown that it is particularly those workers who have especially demanding and dangerous jobs - steelworkers for instance - who develop an emotional attachment to their work. This often goes hand in hand with a need to take risks as part of their masculine identity, and is a fundamental part of certain jobs for men. ${ }^{46}$ In Karl's memories these common work experiences are located at a specific place, the Maxhütte, where work experiences were also place experiences - inclusion into the place ballet for instance, and an actual sense of place.

\section{Conclusion}

Avery Gordon writes that: 'Haunting is a frightening experience. It always registers the harm inflicted or the loss sustained by a social violence done in the past or in the present. ${ }^{47}$ It is such a loss sustained by a social violence that has befallen these workers, with the closure and tearing down of their workplaces. For them, this violence comes to life once again today, through the haunting of what was there before and the emergence of a painful contrast between the former and current state of their workplaces. Using the metaphor of haunting, the loss and the social violence experienced by the workers upon the closure of their companies becomes palpable. The term social violence is used because these people had no say in the transformation of their workplaces and were treated purely as functioning workers within the companies. They once believed, with grave misapprehension, that they were more than that, but again and again, the haunting spectres of today make it clear that this was not the case. This situation lays bare the former workers' belief that they were not just numbers in the production process.

It is a common practice of workers today to encounter a haunting of former times, together with former colleagues; either at the former workplace, or by narrating individual but similar memories. The emotions expressed in the workers' narratives are a product of a specifically class-related sense of place. In their memories, class relates to a specific working place, or, more precisely, to what was there before the place was transformed. The haunting from former times, encountered by workers today as they remember their working lives and visit what is left of the former workplace, brings back memories of a better past. The workers' mourning for the loss of what was there before and is now absent is an emotional expression of class. Confronting the haunting today is therefore also a productive process. Engineering a direct confrontation with the transformed place is a strategy devised by the workers, not only to cope with their loss, but also to ensure their own identities as members of a workers' class with an emotional experience.

The haunting has specific characteristics. It is painful, arrives involuntarily and is repetitive, as it haunts again and again. But the haunting in this article is also seen as class-related as it does not haunt everyone. It affects only those with a specific, class-related experience and sense of place. This article has explored the role of social class in shaping a sense of place. Far from considering the workplace as solely economically driven, it shows that this is where a worker's class-based sense of place can be seen. The workers' own experiences at these places, and their inclusion into a community, have brought about the development of a sense of place. For the worker, the workplace became their friend, or a second family. With the help of life history interviews, a sense of 
place normally hidden within the strictly economically determined narrations of working-class life becomes visible here.

In this article, places have been analysed as experiences and not as representations. But against the background of the article something on the subject of representations can be learned: the workers sense of place, rarely considered in official representations of transformed working places, might be useful for improving social justice. On that note, the workers' memories of their workplaces, and the feelings and experiences that feed their sense of place, should be used to help document and demonstrate the consequences of transformations. This might also encourage social and geographical research to make more of an effort to view the workplace as somewhere that is experienced in everyday life and to which workers have emotional connections that are expressed within their sense of place. Everyday geographies, places and identities are not without a past, and it is through the haunting experienced by workers that this past and the social violence that may have happened can be seen and remembered.

\section{Acknowledgements}

I am very thankful to the interviewees for allowing me to collect their life stories. I would like to thank Tim Cresswell, Pia Gries, Lars Frers, Erika Sigvardsdotter and the reviewers for their very helpful comments and suggestions on my paper. I am also very grateful to Markus Promberger for valuable support and constructive critiques during the research project. Nevertheless, I take personal responsibility for the views expressed in this paper.

\section{Funding}

This research project was funded by the EU in the 7th FP, SSH8-5.2.01.

\section{Notes}

1. The Maxhütte started its blast furnace in 1864. The location, in Rosenberg, was selected because of the nearby ore deposits and because of its position near the railway line between Nuremberg and Regensburg. Following the opening of the Maxhütte, the number of inhabitants in Rosenberg rose sharply and in the following decades it dominated the nearby region. In the 1960s up to 9000 people worked in the Maxhütte and around 95 percent of the workers were members of the industrial workers union. From 1981 the workers struggled against job losses and the threatened closure of the plant. Demonstrations and strikes were widely supported by inhabitants of Sulzbach-Rosenheim. Since, after its first bankruptcy in 1987, the Maxhütte was temporarily partly owned by the federal state of Bavaria, its closure was also of political relevance. After the final closure of the Maxhütte in 2002, a separate pipe plant (Rohrwerk Neue Maxhütte) continued to function and is still open and working today, employing around 450 people. The development of a new industrial area in the 1980s also lowered the mono-industrial dominance of the Maxhütte in the region.

2. To secure anonymity, pseudonyms have been used for the interviewees.

3. A. Pusca, 'Industrial and Human Ruins of Postcommunist Europe', Space and Culture, 13(3), 2010, pp. 239-55.

4. David Harvey, The Condition of Postmodernity (Malden, MA: Blackwell, 1990); Donald Mitchell, Cultural Geography. A Critical Introduction (Oxford: Blackwell, 1998).

5. Tim Edensor, Industrial Ruins. Space, Aesthetics and Materiality (Oxford and New York: Berg, 2005), p. 4.

6. D. DeLyser, 'Presenting Bodie. A map, a Brochure, and a Landscape Text in a California Ghost Town', in Stephan Hanna and Vincent Del Casino (eds), Mapping Tourism (Minneapolis: University of Minnesota Press, 2003).

7. J.F. Maddern, 'Spectres of Migration and the Ghost of Ellis Island', cultural geographies, 15, 2008, pp. 359-81. 
8. D. DeLyser, 'Authenticity on the Ground. Engaging the Past in a California Ghost Town', Annals of the American Geographers, 89(4), 1999, pp. 602-32.

9. Emotions, effect and feelings are different. Feelings are a personal articulation that is biographically related to a person's past experiences. Emotions are the outward display of those feelings and are social events, while effect is an unconscious spontaneous pre-linguistic feeling that is trigged by factors that are out of our control, see B. Massumi, 'Notes on the Translation and Acknowledgements', in Gilles Deleuze and Felix Guattari (eds), A Thousand Plateaus (Minneapolis: University of Minnesota Press, 1987), pp. ix-xx. This happens less in non-narrated situations, and more during immediate body engagements. Non-representational theory focuses particularly on effect. This paper focuses more on the narrated experience, and so is more about feelings expressed as emotions during biographically-related narrations.

10. Pierre Bourdieu, Distinction (London: Routledge, 1996); John Kirk, Class, Culture and Social Change. On the Trail of the Working Class (Houndmills: Palgrave Macmillan, 2007); Ben Rogaly and Becky Taylor, Moving Histories of Class and Communities. Identity, Place and Belonging in Contemporary England (Basingstoke: Palgrave Macmillan, 2009).

11. Karl Marx, Das Elend der Philosophie (Berlin: Dietz Verlag, 1847).

12. P. Jackson and P. Russell, 'Life History Interviewing', in Dydia DeLyser, Steve Herbert, Stuart Aitken, Mike Crang and Linda McDowell (eds), The Sage Handbook of Qualitative Geography (London: Sage, 2010), pp. 172-92; P. Thompson, The Voice of the Past. Oral history (New York: Cambridge University Press, 1992).

13. This article refers to data gained during the SPHERE project (May 2008 until September 2011). The EU founded project (7. FP) is on 'Space, Place and the Historical and Contemporary Articulations of Regional, National and European Identities through Work and Community in Areas undergoing Economic Restructuring and Regeneration' in six European regions in France, UK, Poland, Turkey, Spain and Germany. In each region, 25 life history interviews with people of different ages, genders and occupations, three focus group interviews and 10 expert interviews were conducted.

14. Raymond Williams, Marxism and Literature (New York: Oxford University Press, 1997); Kirk, Trail of the Working Class; John Kirk and Christine Wall, Work and Identity. Historical and Cultural Contexts (Basingstoke: Palgrave Macmillan, 2011).

15. Steph Lawler, Identity. Sociological Perspectives (Cambridge: Polity Press, 2008).

16. K. Plummer, 'The Call of Life Stories in Ethnographic Research', in Paul Atkinson, Amanda Coffey, Sara Delamont, John Lofland and Lyn Lofland (eds), Handbook of Ethnography (London: Sage, 2009), pp. 395-406.

17. J.F. Maddern and P. Adey, 'Special Issue on Spectro-Geographies', Cultural Geographies, 15, 2008; K. Hetherington and M. Degen, 'Special Issue: Spatial Hauntings', Space and Culture, 1, 2001; K.S. Coddingtona, 'Spectral Geographies: Haunting and Everyday State Practices in Colonial and Present-Day Alaska', Social \& Cultural Geography, 12(7), 2011, pp. 743-56; T. Davidson, 'The Role of Domestic Architecture in the Structuring of Memory', Space and Culture, 12(3), 2009, pp. 332-42; M. Bell, 'The Ghosts of Place', Theory and Society, 26, 1997, pp. 813-36; J. Wiley, 'The Spectral Geographies of W.G. Sebald', cultural geographies, 14, 2007, pp. 171-88.

18. Jacques Derrida, Spectres of Marx: The State of the Debt, the Work of Mourning and the New International (London: Routledge, 1994).

19. Avery Gordon, Ghostly Matters: Haunting and the Sociological Imagination (Minneapolis: University of Minnesota Press, 2008), p. 8.

20. Gordon, Ghostly Matters, p. 19.

21. P. Bourdieu, 'What Makes a Social Class?', Berkeley Journal of Sociology, 22, 1987, pp. 1-18; P. Bourdieu, Practical Reason: On the Theory of Action (Stanford: Stanford University Press, 1998); P. Bourdieu, The Logic of Practice (Cambridge: Polity, 1990).

22. Y.F. Tuan, 'Senses of Place - Its Relationship to Self and Time', in Tom Mels (ed.), Reanimating Places - A Geography of Rhythms (Aldershot: Ashgate, 2004), pp. 45-55; J.N. Entrikin, The Betweenness of Place. Towards a Geography of Modernity (Baltimore, MD: John Hopkins University Press, 1991).

23. Maurice Merleau-Ponty, Phenomenology of Perception (London: Routledge, 1962). 
24. John Wylie, Landscape (London: Routledge, 2007).

25. John Wylie, 'A Single Day's Walking. Narrating Self and Landscape on the South West Coast Path', Transactions of the Institute of British Geographers, 30(3), 2005, pp. 234-47; J. Wylie, 'Landscape, Absence and the Geographies of Love', Transactions of the Institute of British Geographers, 34, 2009, pp. 275-89; O. Jones, 'An Ecology of Emotion, Memory, Self and Landscape’, in J. Davidson, L. Bondi and S. Smith (eds), Emotional Geographies (Aldershot: Ashgate, 2005), pp. 205-18; O. Jones, this special issue.

26. Edensor, Industrial Ruins; T. Edensor, 'Waste Matters. The Debris of Industrial Ruins and the Disordering of the Material World', Journal of Material Culture, 10(3), 2005, pp. 311-32; T. Edensor, 'Sensing the Ruin', The Senses and Society, 2(2), 2007, pp. 217-32; C. DeSilvey, 'Observed Decay - Telling Stories with Mutable Things', Journal of Material Culture, 11(3), 2006, pp. 318-38.

27. S. Pile, 'Emotions and Affect in Recent Human Geography', Transactions of the Institute of British Geographers, 35(1), 2010, pp. 5-20; D. Thien, 'After or beyond feeling? A consideration of affect and emotion in geography', Area 37(4), 2005, pp. 450-454; L. Bondi, 'Making connections and thinking through emotions: between geography and psychotherapy', Transactions of the Institute of British Geographers, 30(4), 2005, pp. 433-48; J. Davidson, L. Bondi and S. Smith (eds), Emotional Geographies (Aldershot: Ashgate, 2005).

28. M. Collis, “Mourning the Loss" or "No Regrets". Exploring Women's Emotional Responses to Hysterectomy', in J. Davidson, L. Bondi and S. Smith (eds), Emotional Geographies (Aldershot: Ashgate, 2005, pp. 33-48; K. Anderson and S. Smith, 'Editorial: Emotional Geographies', Transactions of the Institute of British Geographers, 26(1), 2001, pp. 7-10; G. Valentine, 'The Geography of Women’s Fear', Area, 21, 1989, pp. 385-90; J. Sharp, 'Geography and Gender: What Belongs to Feminist Geography? Emotion, Power and Change’, Progress in Human Geography, 33(1), 2009, pp. 74-80; L. Bondi, 'Making Connections and Thinking through Emotions: Between Geography and Psychotherapy', Transactions of the Institute of British Geographers, 30(4), 2005, pp. 433-48.

29. S. Hoelscher and D.H. Alderman, 'Memory and Place. Geographies of a Critical Relationship', Social and Cultural Geography, 5, 2004, p. 348.

30. Steve Pile, Real Cities (London: Sage, 2005).

31. Dolores Hayden, The Power of Place. Urban Landscapes as Public History (Cambridge: MIT Press, 1995), p. 9.

32. Edward Casey, Remembering. A Phenomenological Study (Bloomington: Indiana University Press, 1987); Jones 'Memory, Self and Landscape'.

33. M. Savage, 'Working Class Identities in the 1960s - Revisiting the Affluent Worker Studies', Sociology, 39(5), 2005, pp. 929-46.

34. B. Hernandez, M. Hidalgo, M.E. Salazar-Laplace and S. Hess, 'Place Attachment and Place Identity in Natives and Non-Natives', Journal of Environmental Psychology, 27, 2007, pp. 310-19.

35. G. Rose, 'Place and Identity. A Sense of Place', in D. Massey and P. Jess (eds), A Place in the World? Places, Cultures and Globalisation (Oxford: Oxford University Press, 1995).

36. Irwin Altman and Setha Low (eds), Place Attachments (Plenum Press: New York, 1992).

37. Edward Relph, Place and Placelessness (London: Pion, 1976), pp. 39-40.

38. D. Massey, 'The Conceptualisation of Place', in D. Massey and P. Jess (eds), A Place in the World? Places, Cultures and Globalisation (Oxford: Oxford University Press, 1995), pp. 45-86; D. Mitchell, 'California Living, California Dying. Dead Labor and the Political Economy of Landscape', in K. Anderson, S. Pile and N. Thrift (eds), Handbook of Cultural Geography (London: Sage, 2003), pp. 233-48.

39. Barbara Kirshenblatt-Gimblett, Destination Culture. Tourism, Museums, and Heritage (Berkeley, Los Angeles and London: University of California Press, 1998); DeLyser, 'California Ghost Town'; K. Till, The New Berlin. Memory, Politics, Place (Minneapolis: University of Minnesota Press, 2005); Sybille Frank, Der Mauer um die Wette gedenken - Die Formation einer Heritage-Industrie am Berliner Checkpoint Charlie (Frankfurt: Campus Verlag, 2009).

40. J.F. Maddern and P. Adey, 'Special Issue on Spectro-Geographies’, p. 292. 
41. D. Seamon, 'Body-Subject, Time Space Routines and Place Ballets', in A. Buttimer and D. Seamon (eds), The Human Experience of Space and Place (New York: St. Martins Press, 1980), pp. 148-65.

42. Tim Edensor, Tourists at the Taj. Performance and Meaning at a Symbolic Site (London: Routledge, 1998); see also the 'sidewalk ballet' by Jane Jacobs, The Death and Life of Great American Cities (New York: Vintage Books, 1992[1961]).

43. Karl Marx and Friedrich Engels, The German Ideology (London: Lawrance \& Wishart, 1970).

44. U. Beck, The Brave New World of Work (Cambridge: Cambridge University Press, 2000); U. Beck and E. Beck-Gernsheim, Individualization (London: Sage, 2002). The thesis that works has lost its relevance for social identity is also developed with different foci; for example, by Z. Bauman, Work, Consumerism and the New Poor (Buckingham: Open University Press, 1998) or by A. Gorz, Reclaiming Work: Beyond the Wage-Based Society (Cambridge: Cambridge University Press, 1999).

45. R. MacKenzie, S. Mark, F. Chris, G. Ian, P. Robert and G. Jean, 'All That is Solid Melts into Air. Class, Identity and the Maintenance of a Collective Orientation amongst Redundant Steelworkers', Sociology, 40(5), 2005, pp. 833-53.

46. C. Williams, 'Class, Gender and the Body. The Occupation Health and Safety Concerns of Blue Collar Workers in the South Asian Timer Industry', in M. Quinlan (ed.), Work and Health. The Origins, Management and Regulation of Occupational Illness (Melbourne: Macmillan, 1993).

47. Gordon, Ghostly Matters, p. xvi.

\section{Author biography}

Lars Meier, geographer (MSc) and sociologist (MA, PhD), is Lecturer at the Department of Sociology at the Technical University Berlin. His research interests include migration, urban studies, qualitative methods, work and social inequality. 